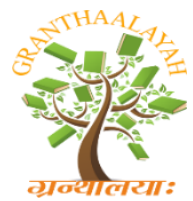

\author{
INTERNATIONAL JOURNAL OF RE
GRANTHAALAYAH \\ A knowledge Repository
}

Social

\title{
ANALYSIS OF THE EFFECT OF LEGAL SOCIOLOGY WITH LAW LOCATED IN SOCIETY
}

\author{
Aldo Ravellio Muljadi *1 \\ ${ }^{* 1}$ Faculty of Law, Universitas Katolik Parahyangan, Indonesia
}

\begin{abstract}
The Sociology of Law is a part of the science of law that examines the interrelationships or the mutual influence between law and social phenomena which is carried out analytically and empirically. Sociology of Law becomes a benchmark in society whether the law to be formed can live in society, and also whether the law that has lived in society becomes law which can then become a legal certainty. The sociology of law can also be a factor of social control, which can then control the norms that exist in society. The results of this study explain that the sociology of law has an influence in the formation of existing laws in society. Because like Roscoe Pond said that "Law is a tool of social engineering" that is law as a tool for social engineering or the community.
\end{abstract}

Keywords: Society; Sociology of Law; Social.

Cite This Article: Aldo Ravellio Muljadi. (2019). "ANALYSIS OF THE EFFECT OF LEGAL SOCIOLOGY WITH LAW LOCATED IN SOCIETY." International Journal of Research - Granthaalayah, 7(11), 138-145. https://doi.org/10.29121/granthaalayah.v7.i11.2020.344.

\section{Introduction}

Legal sociology is a branch of science that analyzes and empirically studies the interrelationships between law and other social phenomena or studies society, especially phenomena in that society. Bernard Arief Sidarta [1] stated: "The sociology of law can be defined as a science based on theoretical analysis and empirical research trying to establish and explain the influence of social processes and people's behavior on the formation, application, jurisprudence and social impact of the rule of law and vice versa the influence of the rule of law on the process social and people's behavior ".

Satjipto Rahardjo [2] said that the object of the sociology of law is the law in terms of reality, namely the law as carried out daily by people in society. So, the law is something that grows and develops in society. Where the law is a value and identity of the community itself. A habit that is present and becomes a rule which is then respected by all parties because it becomes a rule. Based on this definition, it can be concluded that the sociology of law is part of the science of law that examines the interrelationships or reciprocal effects between law and social phenomena that are 
carried out analytically and empirically. So in this context, what law means is the complexity of the attitude of human action that aims to achieve peace in the association of life. Therefore, we can say that the sociology of law has an important role in the process of law formation. Because the sociology of law becomes a reference in shaping law. Based on the description above, the problem discussed in this study is how the influence of sociology of law in law residing in society?

\section{Results and Discussion}

The sociology of law as a new field of science about a number of figures or experts who can be categorized as the foundation of their legal sociology, among others: in Europe, Emile Durkheim, Leon Duquit, Maurice Houriov, Max Weber and Eugen Ehrlich. While the dynamics of the union are known, among others, C.W. Holins, Roscoe Pond, Benjamin Cordoze are also some other names such as Jhering, Talcott Persons.

As a general description of some basic concepts of legal sociology, the author will put forward the main points of teachings from: Emile Durkheim, Max Weber and Roscoe Pond.

\section{Emile Durkheim's Teachings}

Emile Durkheim always questions whether what is really contained in the relationships, structures, and institutions, but still able to have continuity, and remain in strong cohesion and able to survive from time to time? What exactly causes all of them to be bound into a unity? From his thoughts, Durkheim concluded that the cause was "social order the primary of the social" but the most important thing in society was "the social". So, the importance of Emile Durkheim is because he was among the first to see the role of law in shaping his society, now commonly called law and development.

Durkheim distinguishes people from social solidarity and legal types in two types. First, a simple form of society with its mechanical and legal solidarity that is repressive. Second, a complex society with organic solidarity in which the law is repressive. Second, a complex society with organic solidarity in which the law is restitutive. According to him, simple society has mechanical solidarity, that is, among the community members there is a great attachment and that attachment is the basis for the establishment of that simple society. This is what causes relationships in society to be mechanical. Whereas a complex society relies on the freedom and independence of its citizens, because that way, the establishment of a complex society is guaranteed.

\section{Max Weber's Teachings}

Max Weber is a German sociologist and economic expert in legal analysis and legal institutions in it covering the historical context, politics and social reality. He sees law as a dominant element in the development of society. He examines the development of law and the development of society where the basic concept of looking at legal development or the development of society is always moving from the irrational to the rational and the transition from "substantively rational law" to "Formally rational law". So, Weber tends to identify the law with the existence of the law, which is conceptually rationally conceptualized. Because Weber noticed the importance of "rational law" in its causal relationship with the development of capitalism. 


\section{Jhering Teachings}

Jhering is a German Juris famous with his title as "the father of sociological jurisprudence". His systematic doctrine was based on "social utilitarianism" which originated from Betham's "plainpleasure" principle. According to Jhering, the essence of the law is a real will to protect the interests of shared life and individual interests through coordination between the two types of interests. Jhering considers that by coordinating the interests of the community on the one hand and the interests of individuals on the other hand, the possibility of conflict can be minimized. Because he believes that under the law the interests of the community must take precedence over the interests of the individual in the event of a conflict between the two interests. So Jhering's legal concepts are proven to be dominated by teachings about human needs in society.

According to Jhering, law is a set of conditions of social life in the broadest sense, which is enforced by state power through extensive compulsion (external compulsion), so he emphasizes the nature of law on the type of coercion. So finally, the sociological theory of Jhering observes that the actual direction of the law is the realization of a balance between the principles (the principles) and the intent / motivation of the individual on the one hand and the principles and motivations of the community on the other. In his view, law is the embodiment of individual and community alliances.

\section{The Teachings of Ferdinand Tonnies}

His theory about Gemeinschaft and Gesellschaft as two forms that accompany the development of social groups. Gemeinschaft (community) is a form of shared life in which its members are bound by a pure and natural and eternal inner connection. Gesellschaft (patembayan) is a form of life together which is a birth bond that is basic and usually for a short period of time.

\section{Talcott Persons' Teachings}

Talcott Persons is indeed not a sociological law, but one of his social theories called "cybernetics" can be applied to examine the relationship between law and society. he began his cybernetic theory from the parts of the human body which then shaped his "grand theory". Persons sees humans from two views: a) Humans as individuals; and b) Humans as a society.

As an individual he divides humans into 4 sub-systems, namely: cultural systems, social systems, personality and behavioral organisms. Then as a citizen, he distinguishes human life into four subsystems, namely cultural systems, social systems, political systems and economic systems. So, the theory of cybernetics persons is to see the greatest energy flow in the economic sub-system and as it goes downward decreases the opposite is the most information flow in the cultural subsystem and increasingly upward. So, the location of the law lies partly in the cultural subsystem and partly in the social subsystem, it is no wonder that in reality, economic and political forces can influence the implementation of law.

\section{The Teachings of Leopold Wiese}

Sociology is a study of human relations which is a social reality. The special object of sociology is social interaction or social processes. 


\section{Alfred Vierkandt's Teachings}

Sociology mainly studies interactions and the results of those interactions. Society is a collection of social interactions, so that sociology functions to construct theories about society and culture. The basis of all social structures is an emotional bond, there is no conflict between individual and group consciousness, therefore individuals are subject to the goals of the group.

\section{Roscoe Pond's Teachings}

The main views / topics of the Roscoe Pond discussion of the legal sociology are: a) Conducting an analysis of the actual social consequences of legal institutions, and looking at the law in its implementation; b) Emphasizing the sociological aspects of the law in preparation for making the Invitation; c) Prioritize the social goals to be achieved by making regulations and there are no sanctions; d) Discuss the sociological history of law, defend the fair implementation of the law and insist that the teachings of the law are considered as guidelines in a direction that is fair to the community; e) Effectiveness of efforts to achieve legal objectives and the use of legal sociology for the profession of judges and legislators.

From this discussion he brought forth a concept that became very well known, namely "Law is a tool of social engineering", namely law as a tool for social engineering or the community. The sociology of law is needed and is not a new name for a science that has long existed, both the science of law and the sociology of law have the same focus of attention, namely law, but the viewpoints of the two sciences have differences. Law is a socio-cultural phenomenon that functions to apply certain rules and patterns of behavior towards individuals in society. Jurisprudence studies these phenomena and explains the meaning and purpose of these rules, because the rules are often unclear. Various legal rules that apply in society must be classified into a systematic classification, and the core is also one of the tasks of the science of law [3].

Laws that apply in society can also be studied from the point of history. With the historical method, the development of law is examined from the beginning until the occurrence of a set of legal rules. Then the law was compared with other applicable laws in society, to get similarities and differences. They are all objects of research from the history of law and legal science. Law also examines aspects which can be considered as the core or basis of law [4]. This is the task of legal theory.

Another branch of science that focuses on the field of law is legal anthropology, which examines law as a cultural phenomenon. This branch of science is still very young and as is the case with its parent, anthropology, the anthropology of law is particularly concerned with simple societies and traditional elements of societies undergoing a process of modernization [5]. In this case, legal anthropology studies legal processes mainly by examining the causes of disputes, their processes and their resolution.

However, in addition to the aforementioned fields which, among others, are investigated by legal science and legal anthropology. There are other facts which are investigated by law and anthropology of law, namely the patterns of behavior (law) of citizens. The extent to which the law forms patterns of behavior or whether the law is formed from these patterns of behavior. In the first case, what is the most effective way of law in forming behavior patterns? This is the first environmental circle of the sociology of law. 
The subsequent scope concerns the law and patterns of behavior as creatures and forms rather than the desires of social groups. What forces constitute, spread or even destroy juridical behavior patterns. Furthermore, an object that does not receive special attention from legal science or legal anthropology, but is a field of legal sociology research is a reciprocal relationship between changes in law with changes in law with social and cultural changes [6]. To investigate this, sufficient knowledge of the law is needed as a social phenomenon. So, basically the scope of legal sociology is the patterns of behavior in society, namely the ways of acting or behaving in the same manner from people who live together in society. Thus, it can be formulated that the sociology of law is a branch of science which among others examines why humans obey the law and why it fails to obey the law and other social factors that influence it. Legal sociology is a branch of family sociology, industrial sociology, political sociology, or economic sociology. Legal sociology (as well as general sociology) can also be seen as a tool of legal science in examining its objects and for the implementation of legal processes. [7].

The object of the sociology of law itself is not far from the law, society and behavior. One of the objects of legal sociology which then influences the process of legal formation, among others, Law and the Social System of the Community, in essence, this is an overall object of legal sociology, because there is no doubt that a legal system is a reflection of the system social in which the legal system was a part.

However, the problem is not that simple, because it needs to be investigated in what circumstances and in ways that as the social system influences a legal system as a subsystem, and the extent to which the influence process of influencing is reciprocal. For example, does the inheritance system in a community always affect its inheritance legal system. Then the problem arises, whether by introducing and implementing a new inheritance legal system, the old inheritance system will be changed [8]. Such problems are important issues faced by the sociology of law especially because after all, the law can not be separated from the social system of a society.

Law as a social norm or norm cannot be separated from the values that apply in a society. It can even be said that the law is a reflection and concretization of the values that one day apply in society. People who have learned and know what is called law, generally think that a good law is a law that lives in society. This is based on the opinion that to realize the social values aspired by the community, the rules (law) are needed as a tool.

To find out how the relationship between law and the socio-cultural values of the Indonesian people, it needs to be reviewed for a moment the mind of the Indonesian people who for the most part still live and live in rural areas. Indonesian people feel themselves as part of the natural surroundings and all their behavior. To achieve happiness in life, one must adjust to the procedures as determined by the natural surroundings. An act that violates is interpreted, therefore sanctions for violations are aimed at restoring the balance of nature (the cosmic mind) [9].

Regulations in life regarding human behavior, can be known from the orders of parents who passed down from generation to generation, which later became a family habit. Then this family habit is transmitted to other families because in the past the indigenous community lived as a large family group or community that still had kinship. These family habits then become the habits of a group or environment that develops into the culture of community groups, which if there is a new group 
of people who want to be part of this group must obey all the rules and culture of the old group. This culture then becomes a customary law or unwritten law among community groups that are respected and obeyed by all members of the community without realizing who first created it. That's how a law can occur because of social processes.

Legal certainty and comparability are also two main tasks of the law. However, often the two tasks cannot be assigned at once evenly. This, for example, is also emphasized by a sociological figure, namely Max Weber who distinguishes substantive rationality from formal rationality. It is said, that the western legal system has a tendency to put more emphasis on the formal aspect of rationality, meaning that the systematic use of such provisions often contradicts aspects of substantive rationality, that is, the comparability of citizens individually. [10]

The dilemma mentioned above is an interesting theme for the study of legal sociology, for example in examining the possibilities to form a legal system that provides the same degree and opportunity for citizens in carrying out legal actions or establishing a lasting legal system, however quite open to social and cultural changes that occur in society.

Often the laws in society are different from the laws that apply in conflict. Legal regulations regarding the completeness of driving ie helmets cannot be forced in remote villages outside of Java. Due to the lack of city infrastructure that makes at least shops that sell helmets as well as the habit of driving people without using helmets so that the rules regarding the completeness of driving i.e helmets cannot be strictly enforced. This often becomes a dilemma among law enforcers. Therefore, the function of the sociology of law must run well in order to prevent events like this in the future.

Law can be a tool to change society. Law is a community engineering tool. The law has a compelling force that can make a group of people to change and have a new culture. The problem that occurs that makes the law must change the habits of society is the law behind the social changes in society, the effect of a new regulation in the community that must change the habits of society, and finally is to fulfill a sense of community justice. The location or scope of the sociology of law itself there are 2 (two) things, namely: 1) Social Fundamentals of law or social basis of law. An example might be called for example: national law in Indonesia, its social basis is Pancasila, with its characteristics being mutual cooperation, deliberation, and kinship; 2) Legal effects on other social phenomena, for example, can be mentioned for example: a) Law No. 1 of 1974 concerning marriage to the symptoms of domestic life; b) Law No. 22 of 1997 and Law No. 23 of 1999 concerning narcotics and drugs against the symptoms of the consumption of illegal drugs and the like; c) Law No. 19 of 2002 concerning copyright in cultural phenomena; d) Law regarding direct presidential election against political phenomenon [11].

We can say that the sociology of law is a science that theoretically analytically and empirically highlights the influence of other social phenomena on law, and vice versa. Regarding the perspective of legal sociology in general there are two main opinions, namely as follows: a) Opinions that state, that the sociology of law must be given a global function. That is, the sociology of law must produce a synthesis between law as a means of social organization and as a means of justice. In that function, the law can get no small assistance from the sociology of law, in identifying the social context in which the law is expected to function; b) Other opinions state that 
the use of legal sociology is in the field of information and education. Regarding the process of courtship, the sociology of law can reveal data about the constituencies in society that lead to the formation of law (both through rulers' decisions and through joint decrees from members of the community, especially those concerning falkultative law).

From the boundaries, scope and perspective of legal sociology as explained above it can be said, that the use of legal sociology in reality is as follows: a) Legal sociology is useful for providing abilities for understanding of law in social contexts; b) Mastering the concepts of legal sociology can provide abilities to conduct an analysis of the effectiveness of law in society, both as a means of social control, a means of social control, a means to change society, and a means to regulate social interaction in order to achieve certain social conditions; c) Legal sociology provides the possibilities and ability to evaluate the effectiveness of law in society.

These general uses can be explained in detail as follows: 1) At the organizational level in society: a) The sociology of law can express ideologies and philosophies that influence planning, formation, and law enforcement; b) It can be identified which cultural elements affect the content or substance of the law; c) Which institutions are very influential in the formation of law and its enforcement.

At the level of groups in society: a) Disclosure of which groups are very decisive in the formation and application of law; b) Which groups in the community are lucky or vice versa are even harmed by the existence of certain laws; c) Legal awareness rather than certain groups in society.

At the individual level: a) Identification of legal elements that can change the behavior of citizens; b) Strength, ability, and sincerity of law enforcers in carrying out their functions. Compliance of the citizens of the law, both in the form of rules relating to rights obligations, as well as regular behavior.

\section{Conclusion}

The law was born by humans and to guarantee the interests and rights of humans themselves. From this human law and its application will determine what is experienced by humans in the association of life. Law as a tool to change society in the sense that law might be used as a tool by agents of change. An agent of change is a person or group of people who get the trust of the community as leaders of social institutions. A desired or planned social change is always under the control and supervision of the pioneer of the change. It can be said that the rule of law as a tool to change society has an important role, especially in the desired changes, although indirectly. Therefore, if the government wants to form bodies that function to change society, then the law is needed to form the body and to determine and limit its power.

Sociology of law is one branch of law that looks at law from within the community. The sociology of law then views that the realization of good law is the law that was born and grew up in society so that the law can function properly as it should. The sociology of law also considers that effective law is a law that fulfills a sense of community justice. Because one of the characteristics of the law is justice for all people. This sense of justice may differ in each community and social group. 
However, one is certain that this sense of fairness is needed by the community to meet the needs of the community.

The existing law does not all grow from the community and has a basic value that exists in the community. Because the law also functions as a tool to change values in society. Law as a ruler's tool to change circumstances. As Roscoe Pound quotes that "Law is a tool of social engineering", namely law as a tool for social engineering or the community. So that the law for the authorities functions to form new habits as well as a tool for the authorities to determine all the rules that benefit it even though the law is a new thing for the community and the people have difficulties in implementing it.

In this case the sociology of law is not seen by the authorities because even though using legal sociology can determine the right and effective law, but it can be different from the wishes of the authorities. Therefore, the best law is the law that comes from the community, grows from the community, and fulfills the sense of justice of the community itself. Because the law exists for the community and formed the community itself before the existence of an entity called the state as it is now.

\section{References}

[1] Arief Sidharta, Refleksi Tentang Struktur Ilmu Hukum, Bandung: Mandar Maju, 2009.

[2] Satjipto Rahardjo, Ilmu Hukum, Bandung: Alumni, 1991.

[3] Ali, Achmad. Menguak Tabir Hukum (Suatu Kajian Filosofis dan Sosiologis). Cet. II; Jakarta: PT. Gunung Agung, 2002.

[4] Soerjono Soekanto, Pokok-Pokok Sosiologi Hukum, Jakarta: Rajawali Pers, 1980.

[5] Black, Donald. 1989. Sociological Justice. Oxford University Press, New York

[6] Rahardjo, Satjipto. 2010. Sosiologi Hukum. Genta Publishing. Yogyakarta

[7] Roscoe Pound, An Introduction to the Philosopy of Law, New Haven:Yale University Press, 1959.

[8] Sholahudin, Umar. 2011. Hukum dan Keadilan Masyarakat; Perspektif Sosiologi Hukum, Intrans Publishing, Malang.

[9] Max Rheinstein (ed).Max Weber on, Law in Economy and Society. Translated by F. Shils and M. Rheinstein. Cambridge: Harvard University Press, 1954.

[10] Ali Zainuddin, Sosiologi Hukum. Cet. I; Jakarta: Sinar Grafika, 2006

[11] Houte, Van Perspectieven van de Rechtssociologie. Kluwer:Deventer, 1970.

[12] Arif, Zudan Fakrulloh. 2005. Penegakan Hukum Sebagai Peluang Menciptakan Keadilan. Jurnal Jurisprudence, Vol. 2, No. 1, Maret 2005, hal. 22-34

\footnotetext{
*Corresponding author.

E-mail address: aldosusanto52@gmail.com
} 